\title{
Top predators rely on carbon derived from giant kelp Macrocystis pyrifera
}

\author{
Craig Koenigs, Robert J. Miller*, Henry M. Page \\ Marine Science Institute, University of California, Santa Barbara, California 93106-6174, USA
}

\begin{abstract}
Net primary production (NPP) fundamentally shapes ecosystems, but the fate of NPP and its transfer through the food web varies depending on its appeal and availability to consumers. Kelp forests are complex and diverse marine ecosystems, and kelp biomass and NPP can vary widely due to processes including trophic cascades and consequent changes in grazing pressure, storm wave disturbance, and changes in ocean climate and nutrients. Kelp, like other foundation species, clearly modulates the physical environment in which species interact: dense canopies of giant kelp Macrocystis pyrifera shade the reef, shaping the benthic community, and dampen flow through the forest. Yet little quantitative work has investigated the trophic contribution of kelps to kelp forest food webs. Here, we show that giant kelp provides significant trophic support to fishes living in the canopy of the kelp forest. Carbon contributions from kelp, via mesograzer prey, relative to pelagic carbon sources, increased with increasing trophic level of fishes, showing that giant kelp is particularly important to top predators. These findings suggest that losses of giant kelp would have significant consequences for coastal ecosystems and have important implications for the conservation and management of temperate reef ecosystems.
\end{abstract}

KEY WORDS: Ecosystem engineers · Stable isotopes · Trophic subsidy · Detritus · Grazing · Benthic

\section{INTRODUCTION}

Virtually all life ultimately relies on primary production, but the transfer of primary production to higher trophic levels varies with plant tissue nutritional value and other traits, including chemical

\footnotetext{
*Corresponding author: miller@msi.ucsb.edu
}

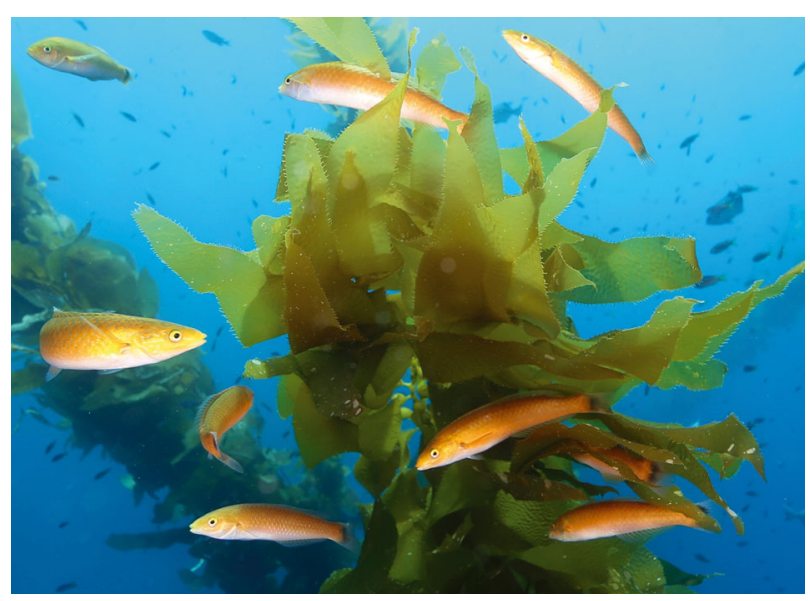

The giant kelp forest canopy is alive with fishes and invertebrates. Here, senoritas Oxyjulis californica are seen feeding on small invertebrates in the kelp.

Photo: Robert J. Miller

defenses that determine palatability (Cebrian 1999, Elser et al. 2000), the physical accessibility of plant tissue to consumers (Soholt 1973), and the strength of top-down control of grazers (Brett \& Goldman 1997). Producer biomass that is unavailable to grazers may be exported out of the system or enter the detritus pool. Negative selection pressure for traits that increase vulnerability to grazing is likely widespread in plants and algae, and may ultimately limit the trophic transfer of primary production (Price et al. 1980, Pohnert et al. 2007). Primary consumers are key to this transfer and thus play a pivotal role in food webs and material cycling in ecosystems (Cebrian 2004).

Many primary producers, particularly those considered foundation species (Dayton 1972, Ellison et al. 2005), do not seem to be significantly impacted by grazing, but clearly create physical structure that

(C) The authors 2015. Open Access under Creative Commons by Attribution Licence. Use, distribution and reproduction are unrestricted. Authors and original publication must be credited. 
alters the ecosystem where they are found (Bruno et al. 2003). Terrestrial examples include trees such as hemlock and mangroves (Ellison et al. 2005). Giant kelp Macrocystis pyrifera is a marine foundation species, forming large forests that alter currents and light on the rocky reefs where they grow, and shaping the entire kelp forest community (Graham et al. 2007). Macrocystis forests are also among the most productive ecosystems on earth (Reed \& Brzezinski 2009) and may support higher trophic levels via both grazer and detrital pathways. Direct grazing rates on Macrocystis, however, are thought to be low, amounting to $\sim 3$ to $6 \%$ of kelp net primary production (Gerard 1976). Moreover, grazing rates in marine ecosystems are thought to be lower in general at the higher latitudes where Macrocystis is found, corresponding with patterns of herbivore diversity and leading to algal dominance of many temperate benthic communities (Gaines \& Lubchenco 1982). A large portion of kelp production is exported to deepwater benthic (Vetter \& Dayton 1998) and intertidal (Dugan et al. 2003) ecosystems, where it provides a substantial allochthonous subsidy. Detrital particulate organic matter (POM) derived from kelp has been widely proposed to be a major food source for sessile suspension feeding invertebrates (reviewed by Miller \& Page 2012), an abundant functional group in kelp forests. However, evidence supporting this pathway is equivocal, and phytoplankton are likely the main food source for reef suspension feeders (Miller \& Page 2012, Miller et al. 2013, Yorke et al. 2013).

Perhaps due to lack of evidence for a major trophic contribution of kelp, many authors have emphasized the physical structure and refuge from predation provided by the kelp canopy, rather than primary production, to explain the high abundance and diversity of fishes in the forest (e.g. Ebeling \& Laur 1985, Angel \& Ojeda 2001, Johnson 2007). Nevertheless, kelp harbors many small invertebrates, including crustaceans and gastropods, which do consume kelp and are prey for higher trophic levels (Graham 2004, Davenport \& Anderson 2007). These mesograzers provide a potential trophic link between kelp production and higher trophic levels in the kelp forest food web that has not been quantified.

In this study, we used stable isotopes and diet analysis to examine the trophic support provided by giant kelp $M$. pyrifera to kelp forest fishes via mesograzer prey. We used 2 groups of primary consumer prey, viz. kelp mesograzers and suspension feeding invertebrates, as proxies for kelp and phytoplankton sources in a Bayesian-framework stable isotope mix- ing model to estimate kelp carbon contributions to fishes. This approach dampens the variability inherent in primary producer isotope values (Vander Zanden \& Rasmussen 1999, Post 2002). We also employed data from gut content analysis as an additional line of evidence for contribution of the 2 sources to fish diets.

\section{MATERIALS AND METHODS}

\section{Field sampling}

Fish were collected by divers in the canopy (0-3 m depth) of 2 kelp forests off Santa Barbara, California, USA: Mohawk $\left(34.394^{\circ} \mathrm{N}, 119.729^{\circ} \mathrm{W}\right)$ and Ellwood $\left(34.426^{\circ} \mathrm{N}, 119.925^{\circ} \mathrm{W}\right)$ reefs. We collected 6 species: blue rockfish Sebastes mystinus $(\mathrm{n}=17)$, kelp perch Brachyistius frenatus $(\mathrm{n}=13)$, giant kelpfish Heterostichus rostratus $(\mathrm{n}=16)$, señorita Oxyjulis californica ( $\mathrm{n}=11)$, kelp rockfish Sebastes atrovirens $(\mathrm{n}=25)$, and kelp bass Paralabrax clathratus $(\mathrm{n}=10)$. Larger fishes were collected using a pole spear, and smaller individuals were collected with a folding net. Fish were immediately covered with ice for transport to the laboratory, where they were measured, dissected for gut content analysis, and muscle tissue sampled for stable isotope composition. Total length (tip of the mouth to tip of the caudal fin), standard length (tip of the mouth to the caudal peduncle), and wet weight were measured.

To sample kelp canopy grazers and suspension feeders, giant kelp Macrocystis pyrifera fronds were collected into fine mesh bags ( $1 \mathrm{~mm}$ mesh) by divers. The fronds were submerged in a bucket of fresh water for $10 \mathrm{~min}$ to release mobile grazers, which were collected on a $1 \mathrm{~mm}$ sieve. Suspension feeders such as the hydroid Obelia sp. and the bryozoan Membranipora serrilamella were carefully removed from kelp blades using scissors and forceps.

\section{Fish gut contents}

The stomach was dissected from each fish, fixed in $10 \%$ buffered formalin for $>24 \mathrm{~h}$, and then transferred to $70 \%$ ethanol. Items in the gut were identified under a dissecting microscope to the most specific taxonomic resolution possible. For each fish, prey items were blotted dry and weighed by taxon to the nearest milligram.

To identify and compare diet among fish species, we analyzed prey mass data with a hierarchical clus- 
Table 1. Mean $\pm \mathrm{SD} \delta^{13} \mathrm{C}$ and $\delta^{15} \mathrm{~N}$ values of study species. Sampling was done from June 2012 to June 2013 with the exception of Macrocystis pyrifera, for which data were taken from Page et al. (2008)

\begin{tabular}{|lrcc|}
\hline Taxon & $\mathrm{n}$ & $\delta^{13} \mathrm{C}(\%)$ & $\delta^{15} \mathrm{~N}(\%)$ \\
\hline Kelp & & & \\
Macrocystis pyrifera & 76 & $-12.5 \pm 1.3$ & $9.7 \pm 1.4$ \\
Invertebrates & & & \\
Idotea resecata & 10 & $-12.7 \pm 1.5$ & $10.5 \pm 1.2$ \\
Peramphithoe humeralis & 5 & $-12.4 \pm 0.6$ & $8.7 \pm 0.4$ \\
Obelia sp. & 5 & $-18.1 \pm 0.6$ & $11.6 \pm 1.0$ \\
Fish & & & \\
Sebastes mystinus & 17 & $-17.4 \pm 0.5$ & $14.2 \pm 0.5$ \\
Brachyistius frenatus & 13 & $-16.9 \pm 0.7$ & $13.9 \pm 0.3$ \\
Heterostichus rostratus & 16 & $-17.0 \pm 0.6$ & $14.2 \pm 0.7$ \\
Oxyjulis californica & 11 & $-16.0 \pm 0.3$ & $14.9 \pm 0.4$ \\
Sebastes atrovirens & 25 & $-15.7 \pm 0.7$ & $15.0 \pm 0.5$ \\
Paralabrax clathratus & 10 & $-15.7 \pm 0.7$ & $15.9 \pm 0.4$ \\
\hline
\end{tabular}

ter analysis using the R package pvclust (Suzuki \& Shimodaira 2006). For this analysis, prey items were categorized into 3 functional groups: kelp grazers, suspension feeders, or small fish (Table 1), and the wet mass of each functional group was averaged among individuals of each fish species. We constructed the model using the average agglomerative method, used correlation to quantify distance between the nodes of the dendrogram, and computed 5000 bootstrap iterations to estimate p-values. Approximately Unbiased (AU) p-values were used to determine significant clustering at the $\geq 95 \%$ level.

\section{Stable isotope analysis and contribution of kelp carbon to fish nutrition}

Tissue samples were dried to constant weight at $60^{\circ} \mathrm{C}$, ground to a fine powder with a ceramic mortar and pestle, and stored in a desiccator until analysis. Following acidification with $10 \% \mathrm{HCl}, \delta^{13} \mathrm{C}$ and $\delta^{15} \mathrm{~N}$ values were measured using a Thermo Finnigan Delta-Plus Advantage isotope mass spectrometer coupled with a Costech EAS elemental analyzer in the UCSB Marine Science Institute Analytical Laboratory (www.msi.ucsb.edu/services/analytical-lab). Instrument precision, determined from replicate analyses of the same standard (NBS 1572, citrus leaf) was $\pm 0.2 \%$. Isotope values are expressed per mil in standard $\delta$ notation relative to the Pee Dee Belemnite standard for $\mathrm{C}$ and atmospheric $\mathrm{N}_{2}$ for $\mathrm{N}$.

We assumed that the principal basal sources of organic carbon available to kelp canopy fishes origi- nated from Macrocystis and phytoplankton (Miller \& Page 2012). We defined 2 kelp canopy primary consumer groups: organisms that graze directly on Macrocystis (kelp grazers) and suspension feeding organisms that feed on phytoplankton. Two known kelp grazers, the isopod Idotea resecata and the amphipod Peramphithoe humeralis, were used as a proxy for kelp-derived carbon. $\delta^{13} \mathrm{C}$ of these species was similar to Macrocystis (mean $\pm \mathrm{SD}=-11.81 \pm$ $1.0 \%$ compared to $-12.50 \pm 1.3 \%$ for Macrocystis, $\mathrm{n}=$ 76, Page et al. 2008). Both species were common in the gut content of some fish species (see 'Results'). Hydroid and bryozoan colonies were used as a proxy for phytoplankton-derived carbon, and had a mean $\delta^{13} \mathrm{C}$ of $-19.00 \pm 0.2 \%$, similar to the mean value for coastal POM (-20.5\%, Miller et al. 2013), the isotope values of which were shown to represent phytoplankton (Miller et al. 2013). Isotope values for these 2 groups were used to represent the end-member values of basal resources available to fishes, in order to better capture temporal variability associated with these sources (sensu Post 2002).

Proportions of source carbon were calculated for each fish species using the Stable Isotope Analysis in $\mathrm{R}$ (SIAR) isotopic mixing model (A. Parnell et al. 2010). SIAR incorporates estimates of error in source, consumer, and trophic enrichment factors that are propagated to the solutions, thereby providing a more robust estimate of uncertainty than most isotopic mixing models (Phillips et al. 2005, A. Parnell et al. 2010). The trophic enrichment factor (TEF) used here in the SIAR model for carbon was $0.34 \pm 1.3 \%$ (DeNiro \& Epstein 1978). We ran the model for $5 \times 10^{5}$ iterations, discarding the first $5 \times 10^{4}$ solutions to control for autocorrelation among the generated solutions (A. Parnell et al. 2010).

\section{Trophic position of reef fish}

We calculated the trophic position (TP) of each fish species as:

$$
T P=\lambda+\left(\delta^{15} \mathrm{~N}_{\text {predator }}-\delta^{15} \mathrm{~N}_{\text {prey }}\right) / \Delta
$$

where $\delta^{15} \mathrm{~N}_{\text {predator }}$ is the mean $\delta^{15} \mathrm{~N}$ value of each fish species, $\delta^{15} \mathrm{~N}_{\text {prey }}$ is the mean $\delta^{15} \mathrm{~N}$ of the prey, and $\lambda$ is a constant that corresponds to the trophic level of the basal trophic position in the system. We set the initial $\lambda=2$ because primary consumers were used for the baseline proxies for carbon supplied to the kelp forest food web (Vander Zanden \& Rasmussen 1999, Post 2002). $\Delta$ represents the TEF of $\delta^{15} \mathrm{~N}$ when $\mathrm{N}$ is transferred from prey to the predator. We used a 
value of $+3.4 \%$ per trophic level, which has been shown to be widely applicable (Post 2002). We used least squares regression to evaluate the relationship between fish trophic position and proportion of filter feeders and kelp grazers in their diet.

\section{RESULTS}

\section{Gut contents}

Approximately $85 \%$ of gut content items could be identified to class or lower. All fishes sampled preyed on both kelp grazers and suspension feeders, but the proportions of the 2 groups varied widely (Fig. 1). Crustaceans were the most prevalent group of prey, and occurred in all samples. Kelp rockfish Sebastes atrovirens (mean \pm SD total length [TL] $=29.32 \pm$ $2.8 \mathrm{~cm}$ ) fed mainly on the kelp-grazing isopod Idotea resecata, which comprised $78.5 \%$ of gut content wet weight in this species. Kelp bass Paralabrax clathratus $(\mathrm{TL}=36.03 \pm 5.1 \mathrm{~cm}$ ), although piscivorous (i.e. fish made up $54.6 \%$ of gut content wet weight), also relied heavily on $I$. resecata $(39.6 \%)$, and consumed significant numbers of kelp-grazing amphipods, including the entire rolled-up kelp blade 'nests' of the amphipod Peramphithoe humeralis, which were found in the guts of several individuals. Giant kelpfish Heterostichus rostratus $(\mathrm{TL}=4.80 \pm 1.0 \mathrm{~cm})$ preyed mostly on a mix of suspension feeding mysid shrimp (60.1\%) and kelp-grazing amphipods (39.9\%). Suspension feeding hydroids comprised $80.0 \%$ of gut content wet weight in blue rockfish Sebastes mystinus $(\mathrm{TL}=15.61 \pm 4.0 \mathrm{~cm}$ ). Diet of the señorita Oxyjulis californica (TL $=18.60 \pm 1.7 \mathrm{~cm}$ ) was variable but was dominated by suspension feeders (9 of 11 taxa).

Cluster analysis revealed 2 distinct groups of canopy fishes based on diet (Fig. 2). S. atrovirens and $P$. clathratus, which consumed mainly kelp grazers and small fishes, clustered together. The other fishes, i.e. S. mystinus, $B$. frenatus, $H$. rostratus and $O$. californica, formed a significant cluster due to the greater relative importance of suspension feeders in their diets.

\section{Contribution of kelp carbon to fish nutrition}

Carbon derived from Macrocystis accounted for $\sim 40 \%$ of tissue carbon in 3 of 6 fish species $(O$. californica, S. atrovirens and P. clathratus; Fig. 3), reflecting the relatively high abundance of kelp

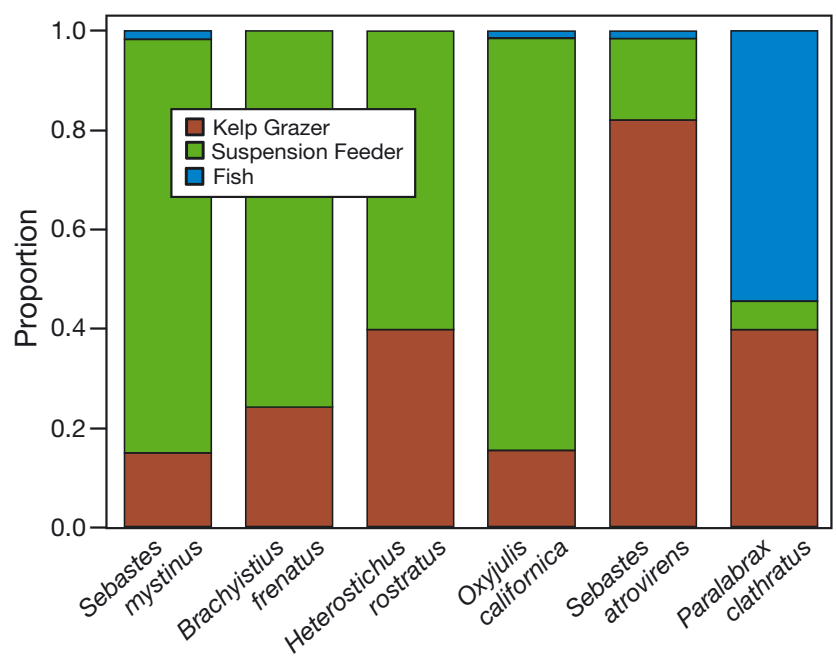

Fig. 1. Proportions of kelp grazers, suspension feeders, and fishes (wet weight in $\mathrm{g}$ ) in the diets of 6 resident fish species of the kelp forest ecosystem

grazers in their diet as demonstrated by the gut content analysis. Phytoplankton-derived carbon was estimated to compose $75-80 \%$ of tissue carbon for the other 3 species ( $S$. mystinus, B. frenatus and $H$. rostratus), reflecting their dependence on suspension feeders for food (Fig. 3). Across fish species, the kelp-derived carbon contribution (SIAR output) and the proportion of wet weight of kelpgrazing organisms in the diet were positively correlated $(\rho=0.53)$.

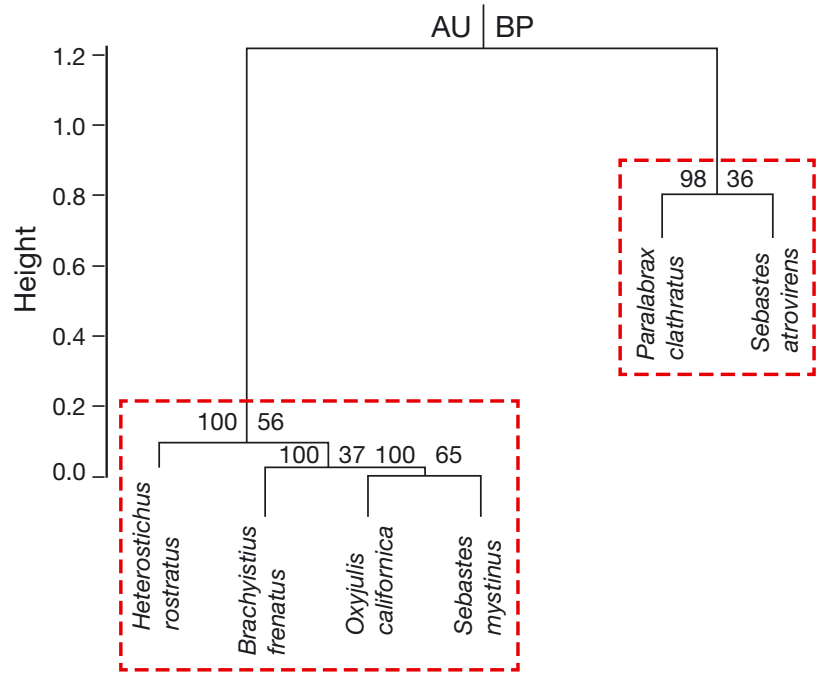

Fig. 2. Dendrogram describing the relatedness of fish species based on gut content data (wet weight in g). Boxes represent significant clusters. At each branch, the left value is the approximately unbiased (AU) $\mathrm{p}$-value and the right value is the bootstrap probability (BP) value, calculated from 5000 bootstrap iterations 


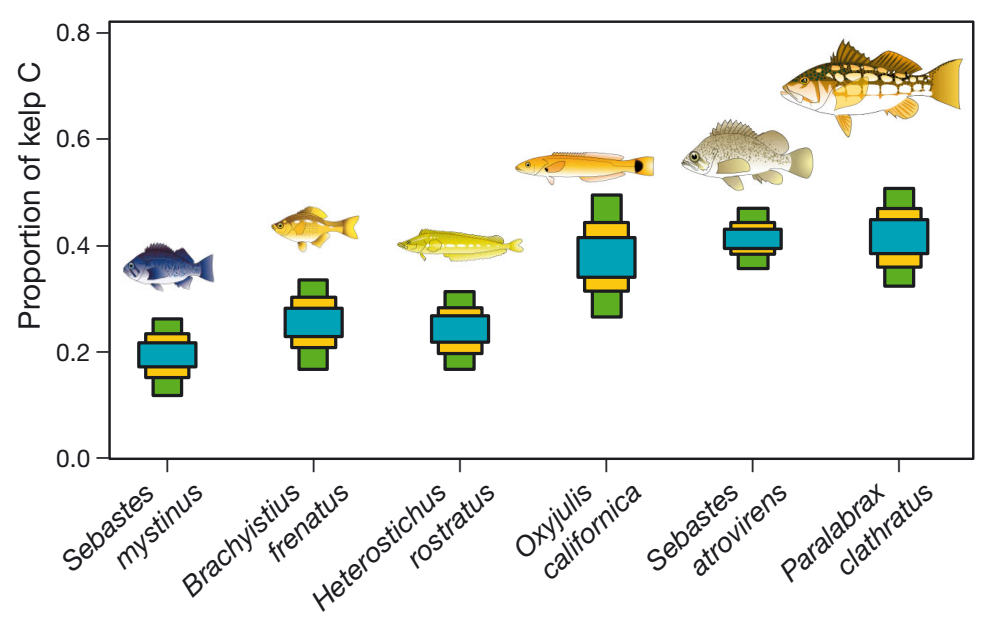

Fig. 3. Proportion of kelp-derived carbon in the diets of the 6 resident fish species. Blue, yellow, and green boxes indicate 95, 75, and 50\% probability densities, respectively

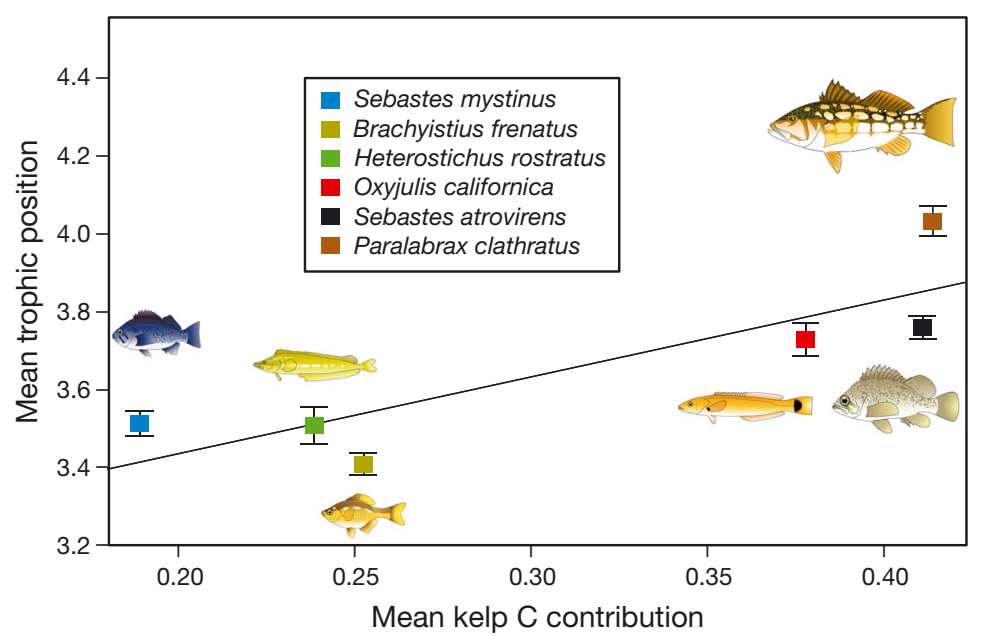

Fig. 4. Mean \pm SE trophic position versus mean tissue kelp carbon contribution (proportion of total carbon), as estimated using SIAR, for all fish species. Line represents least squares regression fit (mean trophic position $=1.99 \times[$ mean kelp C contribution $]+3.03, \mathrm{R}^{2}=0.67, \mathrm{p}=0.03$ )

\section{Trophic position}

$P$. clathratus occupied the highest mean $( \pm \mathrm{SD})$ trophic position at $4.03 \pm 0.1$, with $S$. atrovirens and O. californica close behind at $3.76 \pm 0.2$ and $3.72 \pm$ 0.1 , respectively. S. mystinus $(3.51 \pm 0.1)$, B. frenatus $(3.41 \pm 0.1)$, and $H$. rostratus $(3.51 \pm 0.1)$ were all similar in trophic level. Trophic position (TP) of fish species was positively related to the mean kelp carbon contribution $(K C)$ in their tissue $(T P=1.99 K C+3.03$, $\mathrm{p}=0.03, \mathrm{R}^{2}=0.67$, where $K C$ was calculated using SIAR, Fig. 4).

\section{DISCUSSION}

Here we quantify a clear trophic link between an important marine foundation species, i.e. giant kelp, and higher trophic level fishes in a temperate reef food web. Trophic links between kelp and the reef food web have been qualitatively described (Graham 2004) but seldom quantified. Some omnivores and herbivores, including echinoderms, crustaceans, and mollusks, consume kelp litter on the seafloor (Gerard 1976, Hobson \& Chess 2001), but most large kelp detritus is thought to be exported from the reef (Gerard 1976). Suspension feeders, a major group of primary consumers in kelp forests, have been hypothesized to depend largely on kelp detritus for food (reviewed by Miller \& Page 2012). However, the patterns of stable isotope data that have led to this conclusion are more easily interpreted as the result of variability in phytoplankton isotope values (Page et al. 2008, Miller \& Page 2012, Miller et al. 2013). Our data support previous conclusions regarding the dependence on phytoplankton by this group (e.g. Seiderer \& Newell 1988, Page et al. 2008, Miller \& Page 2012) and that this carbon is also evident in the tissues of higher-level consumers. In fact, despite the importance of kelp mesograzers and kelp carbon to the fishes examined, the majority of carbon in the fishes was derived from phytoplankton.

Taken together, our results suggest that kelp forest food webs depend on both allochthonous phytoplankton-derived carbon and autochthonous kelp carbon, but transfer of the latter source is mediated by mesograzers. Previous research has indicated that fishes eat kelp mesograzers and may control their abundance (Davenport \& Anderson 2007, Pérez-Matus \& Shima 2010). Our results expand on this to show that kelp forest fishes, particularly higher trophic level fishes, depend on kelp mesograzers, and thus on kelp itself, for a significant portion of their dietary carbon. The highest-level predator in our study, the kelp bass Paralabrax clathratus, is generally considered to be a piscivore (Hobson \& Chess 2001), but we found that this species depended significantly on kelp mesograzers for part of its diet. Such feeding on multiple trophic levels by top 
predators is likely more common than appreciated (Page et al. 2014).

Stable isotope values of consumers reflect their diet integrated over time, influenced by the turnover time of the tissue or mixture of tissues measured (Gannes et al. 1997) and by any isotopic fractionation that occurs during incorporation of the elements into tissue (Post 2002). However, use of this tool requires constraining the isotope values of sources and associated error to avoid misleading conclusions (Post 2002, Phillips \& Gregg 2003); ancillary data is also highly desirable to provide alternative evidence for conclusions (Peterson \& Fry 1987). In this study, we used primary consumers to provide an isotopic baseline capturing variability in the isotope values of kelp and phytoplankton (sensu Vander Zanden \& Rasmussen 1999, Post 2002). Diet composition from gut content analysis corresponded well with isotope mixing model results. These 2 independent lines of evidence combined provide compelling support for the conclusion that kelp provides direct trophic support to the higher trophic levels on the reef.

It is possible that the kelp grazers in this study also rely on kelp epiphytes, particularly diatoms, for part of their diet (Bell 1991). Epiphytic diatoms are likely to be quite similar to kelp in their isotope values (Page 1997). Epiphytes would be reflected in the isotopic composition of the grazers if they are eating them, and therefore we implicitly consider epiphytes part of the kelp contribution to fish diets. Disentangling the possible contribution of kelp epiphytes to the canopy food web is an interesting topic for future investigation.

Kelp forests have been the paradigmatic example ecosystem for strong top-down control (Pace et al. 1999), but are also regulated by bottom-up effects (P. Parnell et al. 2010) and disturbance (Dayton 1985, Reed et al. 2008). The relative importance of these processes has been controversial but can depend on the type of kelp, location, and the temporal and spatial scale of observation (Dayton 1985, Steneck et al. 2002, Reed et al. 2014). Clearly, however, kelp abundance is highly variable in space and time no matter the causative mechanisms for this variability, but the consequences of this variability to reef ecosystems are poorly understood. Species composition and richness in the kelp forest are associated with kelp abundance (Graham 2004, Byrnes et al. 2011); in particular, the relative abundance of understory macroalgae and benthic invertebrates often shifts with kelp abundance, likely due to shading and in some cases scouring effects of kelps (Kennelly 1989, Arkema et al. 2009). Our results suggest that fluctuating abun- dance of kelp will also impact higher trophic level fishes through the mesograzer food source. Currently, data on the abundance of kelp mesograzers are scarce to nonexistent, and analyses of forces affecting kelp forest food webs have not included this group (Halpern et al. 2006, Byrnes et al. 2011). For example, Halpern et al. (2006) analyzed the relative importance of bottom-up (chlorophyll concentration) and top-down (abundance of primary and secondary predators) effects on the abundance of algae, which were dominated by kelp, and primary consumers, including herbivores and suspension feeders. They concluded that kelp rockfish Sebastes atrovirens and striped seaperch Embiotoca lateralis exerted significant top-down control that positively influenced algal abundance, and stated that 'both fishes eat a variety of small invertebrates that are not major consumers of algae, and so the mechanism of control on algal abundance is not clear' (p. 1231). Here, we show that one of these species, kelp rockfish, depends heavily on kelp mesograzers. These mesograzers can potentially control kelp biomass (Davenport \& Anderson 2007), but the abundance of kelp and mesograzers may also feed fish and positively influence fish biomass, creating a confounding effect if kelp and fishes are trophically coupled but effects of nutrients on kelp are weak (Halpern et al. 2006 used chlorophyll as a proxy for nutrients). Byrnes et al. (2011) used long-term data on kelp forest community structure to model the effects of increased wave disturbance on kelp abundance and reef food web topology. They found that frequent large storms decreased the diversity and complexity of reef food webs, and that loss of complexity was primarily due to decreases in the diversity of higher trophic levels. Our results provide evidence for a possible mechanism for these changes: loss of kelp as a trophic resource for predators.

The importance of kelp as a trophic resource has implications for management. For example, artificial reefs have been used to mitigate damage to kelp forests. The physical complexity and vertical relief of artificial reefs have often been considered the major factors governing their effectiveness in harboring diverse marine communities, particularly fishes (Bohnsack \& Sutherland 1985). In some cases, such reefs have been designed expressly to support kelp forests (Reed et al. 2006). Our results suggest that this is a good idea; although artificial structure may provide refuge from predation for fishes, kelp has added functional importance as a basal resource in the reef food web, and the importance of kelp-derived carbon to fishes increases with trophic level. 
Acknowledgements. Field assistance was provided by C. Yorke, C. Pierre, C. Orsini, and K. Yaeger. Fish drawings in Figs. $3 \& 4$ were graciously provided by Larry Allen. This work was supported by the U.S. National Science Foundation's Long Term Ecological Research Program under Division of Ocean Sciences awards 9982105 and 0620276, and by NSF Bio-Ocean award 0962306 and an NSF REU supplement to H.M.P. and R.J.M.

\section{LITERATURE CITED}

Angel A, Ojeda FP (2001) Structure and trophic organization of subtidal fish assemblages on the northern Chilean coast: the effect of habitat complexity. Mar Ecol Prog Ser 217:81-91

- Arkema KK, Reed DC, Schroter SC (2009) Direct and indirect effects of giant kelp determine benthic community structure and dynamics. Ecology 90:3126-3137

Bell SS (1991) Amphipods as insect equivalents? An alternative view. Ecology 72:350-354

Bohnsack JA, Sutherland DL (1985) Artificial reef research: a review with recommendations for future priorities. Bull Mar Sci 37:11-39

> Brett MT, Goldman CR (1997) Consumer versus resource control in freshwater pelagic food webs. Science 275 384-386

Bruno JF, Stachowicz JJ, Bertness MD (2003) Inclusion of facilitation into ecological theory. Trends Ecol Evol 18: 119-125

> Byrnes JE, Reed DC, Cardinale BJ, Cavanaugh KC, Holbrook SJ, Schmitt RJ (2011) Climate-driven increases in storm frequency simplify kelp forest food webs. Glob Change Biol 17:2513-2524

$>$ Cebrian J (1999) Patterns in the fate of production in plant communities. Am Nat 154:449-468

> Cebrian J (2004) Role of first-order consumers in ecosystem carbon flow. Ecol Lett 7:232-240

$>$ Davenport AC, Anderson TW (2007) Positive indirect effects of reef fishes on kelp performance: the importance of mesograzers. Ecology 88:1548-1561

Dayton PK (1972) Toward an understanding of community resilience and the potential effects of enrichment to the benthos at McMurdo Sound, Antarctica. In: Parker BC (ed) Proceedings of the Colloquium on Conservation Problems in Antarctica. Allen Press, Lawrence, KS, p 81-96

> Dayton PK (1985) Ecology of kelp communities. Annu Rev Ecol Syst 16:215-245

DeNiro MJ, Epstein S (1978) Influence of diet on the distribution of carbon isotopes in animals. Geochim Cosmochim Acta 42:495-506

> Dugan JE, Hubbard DM, McCrary MD, Pierson MO (2003) The response of macrofauna communities and shorebirds to macrophyte wrack subsidies on exposed sandy beaches of southern California. Estuar Coast Shelf Sci 58: $25-40$

> Ebeling AW, Laur DR (1985) The influence of plant cover on surfperch abundance at an offshore temperate reef. Environ Biol Fishes 12:169-179

> Ellison AM, Bank AS, Clinton BD, Colburn EA and others (2005) Loss of foundation species: consequences for the structure and dynamics of forested ecosystems. Front Ecol Environ 3:479-486

> Elser JJ, Fagan WF, Denno RF, Dobberfuhl DR and others
(2000) Nutritional constraints in terrestrial and freshwater food webs. Nature 408:578-580

Gaines SD, Lubchenco J (1982) A unified approach to marine plant-herbivore interactions. II. Biogeography. Annu Rev Ecol Syst 13:111-138

Gannes LZ, O'Brien DM, Martínez del Rio C (1997) Stable isotopes in animal ecology: assumptions, caveats, and a call for more laboratory experiments. Ecology 78: 1271-1276

Gerard VA (1976) Some aspects of material dynamics and energy flow in a kelp forest in Monterey Bay, California. $\mathrm{PhD}$ dissertation, University of California, Santa Cruz, CA

Graham MH (2004) Effects of local deforestation on the diversity and structure of southern California giant kelp forest food webs. Ecosystems 7:341-357

Graham MH, Vásquez JA, Buschmann AH (2007) Global ecology of the giant kelp Macrocystis: from ecotypes to ecosystems. Oceanogr Mar Biol Annu Rev 45:39-88

Halpern BS, Cottenie K, Broitman BB (2006) Strong topdown control in southern California kelp forest ecosystems. Science 312:1230-1232

Hobson ES, Chess JR (2001) Influence of trophic relations on form and behavior among fishes and benthic invertebrates in some California marine communities. Environ Biol Fishes 60:411-457

> Johnson DW (2007) Habitat complexity modifies post-settlement mortality and recruitment dynamics of a marine fish. Ecology 88:1716-1725

Kennelly SJ (1989) Effects of kelp canopies on understorey species due to shade and scour. Mar Ecol Prog Ser 50: 215-224

Miller RJ, Page HM (2012) Kelp as a trophic resource for marine suspension feeders: a review of isotope-based evidence. Mar Biol 159:1391-1402

Miller RJ, Page HM, Brzezinski MA (2013) $\delta^{13} \mathrm{C}$ and $\delta^{15} \mathrm{~N}$ of particulate organic matter in the Santa Barbara Channel: drivers and implications for trophic inference. Mar Ecol Prog Ser 474:53-66

Page HM (1997) Importance of vascular plant and algal production to macro-invertebrate consumers in a southern California salt marsh. Estuar Coast Shelf Sci 45:823-834

Pace ML, Cole JJ, Carpenter SR, Kitchell JF (1999) Trophic cascades revealed in diverse ecosystems. Trends Ecol Evol 14:483-488

Page HM, Reed DC, Brzezinski MA, Melack JM, Dugan JE (2008) Assessing the importance of land and marine sources of organic matter to kelp forest food webs. Mar Ecol Prog Ser 360:47-62

Page HM, Brooks AJ, Kulbicki R, Galzin R and others (2013) Stable isotopes reveal trophic relationships and diet of consumers in temperate kelp forest and coral reef ecosystems. Oceanography 26:180-189

Parnell AC, Inger R, Bearhop S, Jackson AL (2010) Source partitioning using stable isotopes: coping with too much variation. PLoS ONE 5:e9672

Parnell PE, Miller EF, Lennert-Cody CE, Dayton PK, Carter ML, Stebbins TD (2010) The response of giant kelp (Macrocystis pyrifera) in southern California to low-frequency climate forcing. Limnol Oceanogr 55:2686-2702

Pérez-Matus A, Shima JS (2010) Density- and trait-mediated effects of fish predators on amphipod grazers: potential indirect benefits for the giant kelp Macrocystis pyrifera. Mar Ecol Prog Ser 417:151-158

Peterson BJ, Fry B (1987) Stable isotopes in ecosystem stud- 
ies. Annu Rev Ecol Syst 18:293-320

Phillips DL, Gregg JW (2003) Source partitioning using stable isotopes: coping with too many sources. Oecologia 136:261-269

Phillips DL, Newsome SD, Gregg JW (2005) Combining sources in stable isotope mixing models: alternative methods. Oecologia 144:520-527

Pohnert G, Steinke M, Tollrian R (2007) Chemical cues, defence metabolites and the shaping of pelagic interspecific interactions. Trends Ecol Evol 22:198-204

Post DM (2002) Using stable isotopes to estimate trophic position: models, methods, and assumptions. Ecology 83: 703-718

Price PW, Bouton CE, Gross P, McPheron BA (1980) Interactions among three trophic levels: influence of plants on interactions between insect herbivores and natural enemies. Annu Rev Ecol Syst 11:41-65

Reed DC, Brzezinski MA (2009) Kelp forests. In: Laffoley D, Grimsditch G (eds) The management of coastal carbon sinks. IUCN, Gland, p 31-37

Reed DC, Schroeter SC, Huang D, Anderson TW, Ambrose RF (2006) Quantitative assessment of different artificial reef designs in mitigating losses to kelp forest fishes. Bull Mar Sci 78:133-150

Reed DC, Rassweiler A, Arkema KK (2008) Biomass rather than growth rate determines variation in net primary production by giant kelp. Ecology 89:2493-2505

Editorial responsibility: Katherine Richardson, Copenhagen, Denmark
Reed DC, Rassweiler A, Miller RJ, Page HM, Holbrook SJ (2014) The value of a broad temporal and spatial perspective in understanding dynamics of kelp forest ecosystems. Mar Freshw Res MF14158

Seiderer LJ, Newell RC (1988) Exploitation of phytoplankton as a food resource by the kelp bed ascidian Pyura stolonifera. Mar Ecol Prog Ser 50:107-115

Soholt LF (1973) Consumption of primary production by a population of kangaroo rats (Dipodomys merriami) in the Mojave Desert. Ecol Monogr 43:357-376

Steneck RS, Graham MH, Bourque BJ, Corbett D, Erlandson JM, Estes JA, Tegner MJ (2002) Kelp forest ecosystems: biodiversity, stability, resilience and future. Environ Conserv 29:436-459

Suzuki R, Shimodaira H (2006) Pvclust: an R package for assessing the uncertainty in hierarchical clustering. Bioinformatics 22:1540-1542

Vander Zanden MJ, Rasmussen JB (1999) Primary consumer $\delta^{13} \mathrm{C}$ and $\delta^{15} \mathrm{~N}$ and the trophic position of aquatic consumers. Ecology 80:1395-1404

> Vetter EW, Dayton PK (1998) Macrofaunal communities within and adjacent to a detritus-rich submarine canyon system. Deep Sea Res II 45:25-54

Yorke CE, Miller RJ, Page HM, Reed DC (2013) Importance of kelp detritus as a component of suspended particulate organic matter in giant kelp Macrocystis pyrifera forests. Mar Ecol Prog Ser 493:113-125

Submitted: May 28, 2015; Accepted: August 18, 2015

Proofs received from author(s): September 17, 2015 